\title{
Na granicy faktu. \\ Kategoria faction w badaniach nad współczesnymi biografiami
}

Justyna Tabaszewska

TEKSTY DRUGIE 2019, NR 1, S. 61-79

DOI: 10.18318/td.2019.1.5 | ORCID: 0000-0001-9077-8817

\section{Uwagi wstępne}

Biografie, autobiografie i inne typy literatury zorientowane na przedstawienie opartej na faktach, lub po prostu z faktami zgodnej, opowieści o konkretnej osobie stanowią - jak może przekonać nie tylko analiza rynku książek w Polsce, ale i wizyta w każdej popularnej księgarni - istotną część obiegu współczesnej literatury. W ciągu ostatnich lat przyzwyczailiśmy się, że najczęściej reklamowanymi - i najlepiej sprzedającymi się - książkami są autobiografie lub biografie celebrytów, polityków i aktorów', a intelektualne biografie artystów, choć nie osiągają może tak wysokiego pułapu sprzedaży, trafiają do szerokiego obiegu literatury, wzbudzając dyskusje nie

1 Wystarczy przypomnieć, jak szeroko komentowana była np. autobiografia Danuty Wałęsy oraz wciąż powstające biografie piłkarzy, m.in. Jakuba Błaszczykowskiego (J. Błaszczykowski, M. Domagalik Kuba, Wydawnictwo Buchmann, Warszawa, 2015) oraz Roberta Lewandowskiego (P. Wilkowicz Robert Lewandowski. Nienasycony, Wydawnictwo Agora, Warszawa 2016 oraz Y. Żółtowska-Darska Lewy. Chłopak, który zachwyciłświat, Burda Publishing Polska, Warszawa 2017).
Justyna Tabaszewska

- doktor nauk

humanistycznych,

autorka książek Jedna przyroda czy przyrody alternatywne? O pojmowaniu i obrazach przyrody w polskiej poezji i Poetyki pamięci.Współczesna poezja wobec tradycji i pamięci oraz artykułów publikowanych m.in. w "Tekstach Drugich" i „Przeglądzie Kulturoznawczym". Aktualnie pracuje w Instytucie Badań Literackich nad projektem „Afektywne poetyki pamięci. Polska literatura i kultura wobec przełomu roku 1989 ". 
tylko wśród profesjonalnych literaturo- czy kulturoznawców. Zainteresowanie „prawdziwymi historiami”, „szczerymi opowieściami”, „odbrązawiającymi biografiami" jest więc - zwłaszcza jak na obecną niszowość literatury - powszechne.

Wzrastająca popularność tej formy opowiadania jednostkowych historii przyczyniła się do skomplikowania granic między poszczególnymi gatunkami faktograficznymi. Rozróżnienie na biografię i autobiografię, niegdyś klarowne także dla nieprofesjonalnego czytelnika, mogącego bez trudu odróżnić opowieść o sobie od opowieści o kimś innym, dodatkowo opracowane przez wielu badaczy literatury, z Philippe'em Lejeune'em na czele ${ }^{2}$, stało się obecnie co najmniej problematyczne. O ile formalne rozróżnienie między tymi gatunkami jest dość proste, o tyle jego sens w dobie powszechnego ghost-writing'u stoi pod znakiem zapytania, podobnie jak cała koncepcja paktu autobiograficznego. Jeśli bowiem czytelnik ma świadomość, a coraz częściej tak jest, że to, co nazwane autobiografią, jest spisaną pod kontrolą agenta lub specjalisty od wizerunku biografią znanej osoby, przez nią jedynie podpisaną, to rodzi to wątpliwości wobec sensowności utrzymywania ścisłego rozróżnienia między tymi gatunkami i uniemożliwia zawiązanie paktu między odbiorcą autobiografii a jej twórcą. Piszący nie pisze bowiem sam o sobie, a czytający nie wierzy, że „tak było naprawdę".

Pokrótce opisywane tu renegocjowanie granic nie dotyczy tylko i wyłącznie rozróżniania między biografią i autobiografią, lecz dotyka również całej klasy tekstów niefikcjonalnych ${ }^{4}$. Coraz częściej jako płynne postrzegane

2 Tezy Philippe’a Lejeune'a, rozpropagowane w Polsce między innymi za pomocą publikacji tłumaczenia artykułu Pakt autobiograficzny (P. Lejeune Pakt autobiograficzny, "Teksty: teoria literatury, krytyka, interpretacja" 1975 nr 5) oraz zbioru artykułów (P. Lejeune Wariacje na temat pewnego paktu. O autobiografii, red. R. Lubas-Bartoszyńska, przeł. W. Grajewski, S. Jaworski, A. Labuda, R. Lubas-Bartoszyńska, Universitas, Kraków 2007) stanowią inspirację dla licznych badaczy zajmujących się zarówno problematyką autobiografii, jak i innymi pokrewnymi praktykami tekstowymi (por. zwłaszcza prace Małgorzaty Czermińskiej, Pawła Rodaka, Zofii Mitosek). W tym artykule będę posługiwać się podstawowym rozróżnieniem Lejeune'a głównie ze względu na jego klarowność, wystarczającą do roboczego rozgraniczania biografii i autobiografii.

3 Ten rodzaj łamania konwencji autobiografii godzi więc w samą istotę paktu autobiograficznego, podważając konieczne zaufanie. Jest to zatem zjawisko zasadniczo odmienne od - analizowanej m.in. przez Annę Turczyn - autofikcji. Por. A. Turczyn Autofikcja, czyli autobiografia psychopolifoniczna, "Teksty Drugie” $2007 \mathrm{nr} 1 / 2$.

4 W tym artykule, odwołując się do definicji i konwencji pisania biografii oraz autobiografii, będę posługiwać się XX-wiecznym rozumieniem wspomnianych gatunków. Wcześniejsze tradycje, choć istotne dla kształtowania konwencji biograficznej i autobiograficznej nie są w tym 
są także granice między gatunkami tradycyjnie uznawanymi za fikcjonalne i niefikcjonalne, a to z kolei prowadzi do powstawania kolejnych gatunków „zmąconych", których istnienie i funkcjonowanie sugeruje konieczność przemyślenia, czym rzeczywiście jest „niefikcjonalność” lub „prawdziwość” tekstu.

\section{Faction - ustanowienie kategorii}

W tym artykule chciałabym zająć się jedną z kategorii granicznych, opisujących sposób funkcjonowania zmąconych gatunków. Tą kategorią, sytuującą się na przecięciu co najmniej kilku odrębnych praktyk tekstowych, jest faction. Zwrot ten, zaczerpnięty z anglosaskich badań nad literaturą, nie daje się zbyt zgrabnie przetłumaczyć na język polski, jest bowiem grą słów dwoma pojęciami, fiction i fact, a więc z tym, co fikcjonalne, i z tym, co faktyczne. Kategoria faction sugeruje więc zmieszanie fikcji i faktu, kontaminację nie tylko gatunku, lecz i relacji, jaką ten gatunek nawiązuje z rzeczywistością. Zanim postaram się pokrótce opisać, czym współcześnie ma być faction jako gatunek lub - co lepiej moim zdaniem oddaje sposób funkcjonowania tej kategorii - praktyka albo strategia pisania, warto poświęcić odrobinę uwagi definicji tego terminu.

Faction nie zawsze oznaczało literaturę funkcjonującą na granicy między fikcją i faktem. Pierwotnie - a więc mniej więcej w latach 6o. XX wieku - faction miało nieco inne konotacje: termin ten odwoływał się do pojęcia powieści niefikjonalnej (non-fiction novel) i stanowił skrótowe oraz wygodne słowo-klucz dla wszelkich typów powieści, opartych na faktach, ale korzystających z wzorców narracyjnych powieści fikcjonalnych ${ }^{6}$. Za przykład i zarazem tekst prekursorski dla tak rozumianego faction najczęściej uznaje się Z zimną krwią Trumana Capote'a7. Wydana w 1966 roku książka została oparta na szczegółowym i dokładnym materiale faktograficznym dotyczącym

tekście, dotyczącym zmian, jakim wspomniane gatunki ulegają w ostatnich latach, z konieczności uwzględnione. Dotyczy to zwłaszcza postrzegania takich zagadnień jak obowiązek prawdziwości, obiektywności czy autentyczności.

5 Por. C. Geertz O gatunkach zmąconych (Nowe konfiguracje myśli społecznej), przeł. Z. Łapiński, "Teksty Drugie" $1990 \mathrm{nr} 2$.

6 Taką definicję powieści niefikcjonalnych przyjmuje m.in. Oxford Dictionary of Literary Terms. Por. Ch. Baldick Oxford Dictionary of Literary Terms, Oxford University Press, Oxford 2015, s. 252-253.

7 Por. T. Capote In Cold Blood. A True Account of a Multiple Murder and Its Consequences, Penguin Books, London 1966. 
morderstw popełnionych 15 listopada 1959 roku. Capote przez kilka lat śledził doniesienia prasowe dotyczące zbrodni oraz prowadził rozmowy z osobami w jakiś sposób z nią związanymi (policjantami, dziennikarzami, sąsiadami, dalszą rodziną ofiar, a także ze skazanymi za zamordowanie rodziny Clutterów Richardem Hickockiem i Perrym Smithem), a całą opowieść oparł na materiale zebranym w ramach tak prowadzonego śledztwa. Opublikowaniu $Z$ zimna krwia towarzyszyła w zasadzie od razu pogłębiona dyskusja dotycząca funkcjonowania książki, sytuującej się na przecięciu reportażu, powieści oraz - do pewnego stopnia - biografii. I tak niejasną sytuację publikacji komplikowały równocześnie: wypowiedzi autora (twierdzącego, że całość została oparta na faktach i nie ma w książce żadnego fragmentu, który nie byłby z faktami spójny - o czym upewniają m.in. zapowiedzi książki na okładce), zaangażowanie Capote’a w proces sądowy sprawców, zwłaszcza zaś próba uratowania jednego z nich od kary śmierci (co było niekiedy poczytywane za przejaw stronniczości), negatywna reakcja lokalnej społeczności Holcomb (urażonej opisami miasteczka), tocząca się ówcześnie w USA (i do pewnego stopnia trwająca do tej pory) dyskusja nad sensownością kary śmierci, ogromne zaangażowanie mediów w sprawę morderstwa Clutterów, a wreszcie powszechne zainteresowanie samym Capote'em (jego efektem są m.in. takie filmy jak Zzimną krwią, reż. R. Brooks, Capote, reż. B. Miller, Bez skrupułów, reż. D. McGrath). Wobec tych wszystkich czynników sama książka i jej - bardzo interesująca - konstrukcja zeszły na dalszy plan ${ }^{8}$. Dla porządku warto ją jednak pokrótce omówić.

Książka zaczyna się od opisu miasteczka, w którym dokonano morderstwa, oraz od przedstawienia czytelnikowi - za pomocą narracji trzeciosobowej - zasad funkcjonowania społeczności Holcomb, w tym roli, jaką odgrywał w niej Herbert William Clutter, jedna z ofiar morderstwa. Narracja trzeciosobowa jest prowadzona konsekwentnie, zarówno w przypadku opisów osób i miejsc, jak i w przypadku rekonstrukcji zdarzeń, w tym - morderstwa na rodzinie farmerów. Dialogi i monologi wewnętrzne postaci (których, jak na ten typ powieści, jest całkiem sporo) wprowadzane są również przez

8 Burzliwość odbioru książki pokazują wciąż ukazujące się artykuły dotyczące możliwych manipulacji Capote'a, por. B. Macintyre "Z zimna krwiq", czyli wielka fikcja Trumana Capote, "The Times", www.polskatimes.pl/artykul/764957,z-zimna-krwia-czyli-wielka-fikcja-trumanacapote, id,t.html (06.06.2018) oraz W. Pavia Genialny manipulator. Truman Capite z zimną krwiq nabrałczytelników na całym świecie, „The Times", http://www.polskatimes.pl/artykul/3683462genialny-manipulator-truman-capote-z-zimna-krwia-nabral-czytelnikow-na-calym-swiecie, id,t.html (06.06.2018). 
narratora wszechwiedzącego i nie są w żaden sposób strukturalnie wyodrębnione (funkcjonują jako równoprawny element świata przedstawionego, nie są oznaczone jako rekonstrukcja zdarzeń lub przypuszczenie, nie funkcjonują również jako cytaty zasłyszanych rozmów, choć w niektórych przypadkach dialogi ujęte są w cudzysłowach, co sugeruje ich odmienny od reszty tekstu status). Narrator pozostaje w obrębie tekstu instancją niesproblematyzowaną, nie ma żadnych wewnątrztekstowych odniesień sugerujących jego tożsamość. Zabieg ten jest o tyle interesujący, że wstęp i podtytuł książki jasno wyznaczają ramy interpretacyjne tekstu w obrębie literatury faktu: podtytuł mówi wprost, że jest to "prawdziwy opis wielokrotnego morderstwa”, zaś słowo wstępne informuje, że wszystko, co znajduje się w tekście,jest w całości oparte albo na doświadczeniach autora, albo na jego lekturach materiału dowodowego lub wywiadach z poszczególnymi osobami.

Wstęp i podtytuł tekstu sugerują więc przyjęcie konwencji reportażowej, natomiast struktura książki odpowiada tradycyjnie rozumianej powieści kryminalnej. Konwencja powieści kryminalnej bywa jednak od czasu do czasu łamana, zwłaszcza przez próbę zakreślenia szerokiego socjologicznego tła wydarzeń w Holcomb, niemniej sama „powieściowość” książki nie zostaje naruszona nigdy. Jest to w całości świadomy zabieg, pozwalający na zastąpienie postaci reportera, którym na potrzeby tej książki stał się Capote, instancją narratora. Decyzja o napisaniu Z zimną krwią w konwencji powieści pozwoliła nie tylko na stworzenie gatunku hybrydowego, lecz również na poszerzenie - w stosunku do reportażu - granic tego, co może zostać opowiedziane, przy równoczesnym praktycznie całkowitym wycofaniu z pola uwagi instancji mówiącej. Osobowy reporter, noszący imię i nazwisko, możliwy do zidentyfikowania oraz podatny na zarzuty dotyczące zbierania lub interpretacji materiału, został zastąpiony bezosobową instancją narracyjną, w całości wtopioną w świat przedstawiony.

Ze względu na to konsekwentne połączenie typowej narracji powieściowej z - deklarowanym przez autora i raczej zgodnym z rzeczywistością - przestrzeganiem zasad zdobywania materiałów zgodnie z zasadami sztuki dziennikarskiej Z zimną krwia zostało uznane twór wyznaczający zasady nowego gatunku: powieści niefikcjonalnej.

Pojawiające się zarzuty stronniczości - o których wspominałam wcześniej - nie zmieniły tej klasyfikacji, lecz wyczuliły krytyków na problemy wynikające z tworzenia tak rozumianych form hybrydycznych, sytuujących się na granicy fikcji i faktu. W konsekwencji powyższe, odnoszące się do powieści niefikcjonalnej, znaczenie faction, funkcjonowało w obrębie 
angloamerykańskiego literaturoznawstwa stosunkowo krótko, bowiem już pod koniec lat 70. powieść niefikcjonalna zaczęła tracić na znaczeniu, a ukształtowana za pomocą Z zimną krwią zasada połączenia szczegółowego materiału faktograficznego z fikcjonalnymi dialogami przestała być respektowana. Do powolnego zmierzchu gatunku przyczyniły się bez wątpienia zarzuty stawiane kolejnym powieściom z tego nurtu, dotyczące - z grubsza rzecz biorąc - tworzenia powieści całkowicie fikcjonalnych, których osadzenie w rzeczywistych zdarzeniach jest albo wybiegiem narracyjnym, albo wręcz świadomą mistyfikacją.

Pojęcie faction, mimo kryzysu gatunku, który wprowadził je w obręb namysłu nad literaturą, nie zniknęło jednak zupełnie. W ostatnich latach daje się zauważyć nie tylko powrót do stosowania tej kategorii, ale również nasilone zainteresowanie twórców eksplorowaniem możliwości, jakie daje połączenie fikcji i faktów. O ile jednak początkowo faction funkcjonowało jako pogranicze powieści i reportażu, teraz zdecydowanie częściej zbliża się do powieści biograficznych. Ponadto - jak postaram się zaraz pokrótce pokazać - termin ten przeszedł znaczącą ewolucję.

\section{Ewolucja faction}

By uchwycić zmianę, jakiej podlega współczesne rozumienie faction, warto moim zdaniem odwołać się do tez Geoffreya Hartmana, badacza, który analizuje relacje między autentycznością i prawdą w różnych typach twórczości opierającej się na faktach. Punktem wyjścia rozważań Hartmana jest opisanie zmian, jakim podlega współcześnie rozumienie dwóch kategorii: realizmu i autentyczności. W książce Scars of the Spirit. The Struggle Against Inauthenticity naukowiec stawia tezę, że we współczesnym świecie, w którym wciąż zmieniają się kryteria, wedle których uznajemy dane rzeczy za możliwe lub niemożliwe, zmianie ulega również nasze postrzeganie rzeczywistości. Gdy realne jest klonowanie, a postęp technologii zdaje się nie mieć granic, autentyczność staje się - nieco paradoksalnie - bardzo pożądaną wartością9. Równocześnie, jak zauważa Hartman, kategoria ta jest coraz częściej używana w kontekstach, które niewiele mają z nią wspólnego lub - co jeszcze trudniejsze do zaakceptowania - „autentyczność”" służy jako namiastka prawdziwości. A to oznacza, że „z wyjątkiem samej kategorii «duchowości»,

9 G. Hartman Scars of the Spirit. The Struggle Against Inauthenticity, Palgrave Macmillan, New York 2002, s. x. 
«autentyczność» może być najbardziej nieautentyczną kategorią w otaczającym nas świecie"10.

"Autentyczność", zarówno ta prawdziwa, jak i ta „nieautentyczna”, stała się zdaniem badacza szczególnie ważną kategorią współcześnie, gdyż jest ona używana na nieznaną wcześniej skalę w procesach budowania własnego lub cudzego publicznego wizerunku, a więc - między innymi - podczas tworzenia swojej lub cudzej biografii. To zaś sprawia, że dzisiaj patrzymy już zupełnie inaczej na tworzenie „autentycznych” biografii:

Autentyczna osoba nie powinna sztukować swojej tożsamości, poświadczając swoje pochodzenie, genealogię rodziny oraz nieustannie powołując się na wyznawaną wiarę, uczciwość lub osiągnięcia. Tymczasem jesteśmy już wszyscy znudzeni, wysłuchując kolejnych wypowiedzi polityków na temat ich miejsca urodzenia i korzeni (im bardziej swojskich, tym lepiej) $[\ldots]^{11}$

Budowanie $u$ innych poczucia autentyzmu stało się ostatnimi czasy obowiązkiem każdego, komu zależy na zainteresowaniu. Równocześnie taka eksploatacja tej kategorii do pragmatycznych celów spowodowała zupełną utratę społecznego zaufania: jeśli ktoś na siłę konstruuje poczucie autentyczności, najczęściej jest postrzegany jako nieautentyczny, ale zarazem jeśli tego nie czyni, nie jest w stanie zakorzenić się w powszechnym kulcie tego, co „prawdziwe”. Obowiązek autentyczności - nawet jeśli niespełnialny - zaczął obejmować nie tylko budowanie własnego wizerunku, lecz także szeroko rozumianą sztukę, która, by być doceniania, musiała być „autentyczna”, cokolwiek miało to znaczyć.

Opisywany przez badacza proces inflacji kategorii autentyczności obejmuje zatem różne aspekty kultury: z jednej strony staje się powszechnym wymogiem, zgodnie z którym każdy musi być autentyczny, z drugiej w jakiś sposób „autentyczne" mają być również te rodzaje aktywności, które w pewnym sensie „autentyczne” być nie mogą. O ile „autentyczność” w odniesieniu do budowania własnego wizerunku i biografii miała nakazywać zgodność z prawdą, o tyle takie rozumienie autentyczności jest niemożliwe do pogodzenia z trybem funkcjonowania sztuki. Celem sztuki nie jest przecież i być nie może tworzenie tekstów kultury lub dzieł, które mają nawiązywać ścisłą

\footnotetext{
10 Tamże, s. 5 .

11 Tamże.
} 
relację prawdziwości ${ }^{\mathbf{1 2}}$ ze światem zewnętrznym. Autentyczność w tym przypadku musi być realizowana inaczej' ${ }^{13}$.

O tym, jak postulat ten może być realizowany, zaświadcza zdaniem Hartmana współczesne upodobanie do tropienia biografii i losów artystów: autentyczne w tym rozumieniu jest nie tyle samo dzieło, lecz jego związek, z osobą, która je wytworzyła. Pierwszym, koniecznym warunkiem tropienia tak rozumianej autentyczności jest zatem prawidłowa atrybucja ${ }^{\mathbf{1 4}}$. Jest ona warunkiem nie tylko przypisania danego dzieła do określonego autora, lecz ma także odpowiadać za możliwość powiązania wytworu z umysłem twórcy, a więc pozwalać na uprawomocnienie go jako autentycznego psychologicznie. Pod tym względem rozumienie autentyczności przyjmowane przez Hartmana jest bliżej pojęcia wierności i szczerości wobec własnych przeżyć niż np. kategorii obiektywności, często przywoływanej w podobnych kontekstach ${ }^{15}$.

Jednak, jak pokazuje badacz, nawet tak rozumiana autentyczność zdaje się we współczesnych czasach nie wystarczać: odbiorcy sztuki coraz częściej szukają transparentnego związku między wytworem artysty a jego życiem. To zaś odpowiada - przynajmniej częściowo - za współczesną inflację pisarstwa i twórczości niefikcjonalnej. Przekonanie, że to, co autentyczne,jest prostym odpowiednikiem prawdziwych wydarzeń z życia twórcy, prowadzi jednak do dalszych problemów i paradoksów. Poszukiwaniu absolutnej autentyczności towarzyszy bowiem przekonanie, że absolutna szczerość, tak jak i całkowita transparencja, nie jest możliwa. A w takim przypadku autentyczność jest nie

12 Hartman, pisząc o „prawdziwości”, zdaje się posługiwać referencjalną teorią prawdy, lecz nie jest to przez badacza wprost dookreślone.

13 Tamże, s. 7.

14 Co ciekawe, kwestia atrybucji ma największe znaczenie w bardzo konkretnym przypadku, wiążącym się z postrzeganiem problemu autentyczności: przypisywaniem dzieł, zwłaszcza wizualnych, konkretnym autorom. To, czy dany obraz jest "autentycznym" dziełem danego, zwłaszcza znanego artysty, pozostaje nie bez wpływu nie tylko na ocenę artystyczną dzieła, lecz także - co zdaniem badacza istotne - także na jego wartość rynkową. Tamże, s. 8.

15 Kategoria obiektywności nie pojawia się poza tym fragmentem tekstu w moich rozważaniach nieprzypadkowo. Choć w niektórych sposobach definiowania gatunków niefikcjonalnych, zwłaszcza zaś tych, dla których nadrzędna jest relacja prawdziwości, odpowiedniości między tym, co opisane i tym, do się wydarzyło, Hartman unika jakichkolwiek odniesień do wspomnianej kategorii. Autentyczność, w tym rozumieniu, jakie badacz przyjmuje, nie polega na odpowiedniości między wydarzeniem a opisem wydarzenia, lecz między wydarzeniem a przeżyciem lub postrzeganiem owego wydarzenia. W takim zaś przypadku "autentyczność" ma o wiele większe znacznie od "obiektwyności”. 
tyle postawą, która ma na celu odsłonięcie tego, co istotne dla tożsamości danej osoby, ile strategią mającą na celu zainteresowanie odbiorcy. Równocześnie - jak Hartman pokazuje za pomocą analizy między innymi Jądra ciemności ${ }^{16}$ - poszukiwanie autentyczności w sztuce nie musi wcale koniecznie wiązać się z próbą tworzenia tekstów niefikcjonalnych.

Badacz rozdziela w swoim wywodzie dwa zasadniczo odrębne rozumienia autentyczności: pierwsze wiąże się z konstrukcją tekstu lub dzieła, które szuka uwiarygodnienia w relacji ze światem zewnętrznym (jak np. literatura faktu) lub w relacji z konkretną osobą (jak w przypadku biografii lub autobiografii), drugie z reakcją odbiorcy, który bez względu na umocowanie - lub nie - tekstu w obrębie określonych faktów lub prawd może tekst uznać za autentyczny. W obu przypadkach istotne dla Hartmana jest jednak kryterium uczciwości, rozumiane jako możliwość odróżniania prawdy od kłamstwa. A - co warto podkreślić - kłamstwo nie jest wcale równoznaczne z fikcją, gdyż możliwe jest nawet użycie fikcji w przypadku gatunków klasycznie kojarzonych z faktem (np. w biografii), w taki sposób, by wymogu uczciwości nie naruszać. W takim jednak przypadku fikcjonalizacja musi być dla czytelnika jasna i nie stanowić chwytu uzasadniającego traktowanie danego tekstu jako "prawdziwego"

Przykładem tak rozumianego użycia fikcji w odniesieniu do biografii jest zdaniem Hartmana Blonde Carol Oates - fikcjonalizowana biografia Marilyn Monroe. Oates w swojej książce potraktowała życie Marilyn Monroe jako kanwę opowieści, w której wszystkie istotne fakty z życia aktorki pozostają zgodne z wydarzeniami opisanymi w książce, możliwe jest również - i stosunkowo nietrudne - odkrycie, o kim jest to opowieść (sama Monroe występuje najczęściej jako tytułowa „Blond Aktorka", natomiast inne ważne w jej życiu osoby występują albo pod zmienionymi nazwiskami, albo łatwymi do zrozumienia pseudonimami,

16 W tym przypadku autentyczność jest nie celem samym w sobie, lecz skutkiem udanego eksperymentu artystycznego, w którym za pomocą fikcjonalnej narracji zostają przedstawione prawdziwe, istotne dla ówczesnego społeczeństwa problemy oraz uzasadnione psychologicznie reakcje na nie. Autentyczność nie jest w tym przypadku konsekwencją naddanej relacji między tekstem a światem zewnętrznym, lecz skutkiem konkretnej strategii artystycznej. Por. tamże, s. 11.

17 Tzw. strategie uwiarygodnienia (np. sugerowanie, że dany tekst jest cudzym dziennikiem, pamiętnikiem, itp.) są pod tym względem wyjątkowo problematyczne. Zdaniem Hartmana nie mogą być stosowane do tekstów innych niż fikcjonalne, gdyż zaburzają podstawą dla funkcjonowania literatury faktu relację zaufania. Por. tamże, s. 26. 
jak: „Były-Sportowiec” - Joe DiMaggio, „Książę” - prezydent Kennedy, "Dramatopisarz" - Arthur Miller), niemniej mimo tak oczywistych sygnałów odpowiedniości między opisywaną historią a wydarzeniami z życia artystki oraz faktualnej dokładności nie znajdziemy w tekście żadnych zapewnień o „autentyczności” tej historii. Przeciwnie, zdaje się ona funkcjonować jako w całości fikcjonalna ${ }^{\mathbf{1 8}}$, mimo że podobieństwo do określonych wydarzeń i osób jest trudne do przegapienia. Strategia, jaką stosuje Oates, jest zdaniem Hartmana podobna do innych zauważalnych tendencji mieszania literatury fikcjonalnej z literaturą faktu (takich jak m.in. przenoszenie historycznych wydarzeń do teraźniejszości) ${ }^{\mathbf{1 9}}$.

Książka Oates, choć wytwarza pozór fikcjonalności, zachowuje jednak i zasadę realizmu, i zasadę niesprzeczności z faktami, a te dwa warunki są zdaniem Hartmana konieczne do tego, by dany tekst uznać za spełniający warunki faction. Mieszanie faktów i fikcji musi więc przebiegać na zasadzie niesprzeczności: elementy fikcjonalnie nie mogą podważać prawdopodobieństwa świata przedstawionego, w tekście nie może być bezpośrednich sygnałów pozwalających na falsyfikację zdarzeń, ale równocześnie nie wszystko, co w tekście się znajduje, musi być wiernym odwzorowaniem rzeczywistych zdarzeń. Odbiorca ma pozostawać w pewnym zawieszeniu, nie może określić (na podstawie sygnałów wewnątrztekstowych), czy przedstawiony świat jest realny, czy fikcjonalny.

Tak rozumiane faction służy wykreowaniu specyficznej postawy u odbiorcy: nie jest to, jak w przypadku autobiografii definiowanej przez Lejeune'a, pakt zasadzający się na zaufaniu, lecz raczej swoista gra, wymagająca od twórcy przestrzegania pewnych zasad (a więc zasady niesprzeczności z faktami i realizmu) a od odbiorcy - znajomości konwencji. Popularność faction zdaje się wynikać bezpośrednio z dwóch czynników: pierwszym jest zainteresowanie literaturą faktu, drugim jednak dostrzeżenie, że kwestia prawdziwości, uczciwości lub autentyczności nie jest wcale jasno zdefiniowania nawet wewnątrz najmocniej uwiarygodnianych zapisów:

Teraz na teksty wspomnieniowe i biografie patrzymy raczej jako na formę ekspresywnej i zarazem impresywnej literatury, niż jako ściśle

18 Co zresztą prowadziło do oskarżeń wobec Oates, której zarzucano użycie życia Marilyn Monroe jako kanwy opowieści jako substytutuu własnego pomysłu. Hartman, co pokazuje, krytykując recenzję Michiko Kakutani, uznaje te oskarżenia za zupełnie bezpodstawne.

19 Tamże, s. 56. 
faktograficzne dokumenty. Biograf, jak powiadają, jest powieściopisarzem tworzącym pod przysięgą. Współczesny termin ,faction"wskazuje na radykalną zmianę wrażliwości, z którą wciąż sobie radzimy. Historia, zwłaszcza współczesna historia, staje się bardzo szybko przestrzenią re-kreacji [...]. Znaczące jest, że Edmund Morris, biograf i autor książki Dutch o życiu Ronalda Regana [...] wpisuje sam siebie w życie Regana jako świadek wydarzeń przed rokiem 1985, a więc rokiem, w którym rzeczywiście zyskał dostęp do polityka. Włączając się we wcześniejsze historyczne zdarzenia, Morris buduje intymną relację z opisywanymi zjawiskami, która - choć fałszywa - pełni w tekście istotną rolę..$^{20}$

Podsumowując, Hartman uznaje, że kategoria faction jest odpowiedzią na dwie sprzeczne, lecz zarazem wyraźne tendencje we współczesnej kulturze: szukania autentyczności i niewiary w możliwość jej osiągnięcia. Prowadzi to do mieszania opartych na fikcji i faktach gatunków, zazwyczaj - jak pokazuje choćby analizowany wcześniej przykład książki Oates - przez wprowadzanie do jednego gatunku chwytów znanych z innego. Kanwą faction może być zarówno powieść (do której dodaje się np. elementy reportażu lub autobiografii), jak i gatunki oparte na fakcie: fikcjonalizowane reportaże lub biografie. Zabiegi owocujące rozmiękczaniem gatunkowych różnic czasem stosowane są przez twórców świadomie - jak na pewno w przypadku Oates czy Capote'a, a czasem - nie do końca świadomie. Nie zmienia to jednak zasadniczo cech samego zjawiska, opierającego się na przekroczeniach, rekonstrukcjach czy zmianach dokonywanych w obrębie rozróżniania faktu i fikcji. Pod tym względem faction nie jest gatunkiem, lecz raczej strategią, opierającą się tworzeniu gatunków zmieszanych, zmąconych, funkcjonujących na granicy faktu i fikcji. Kanwą dla faction może być każdy - i fikcjonalny, i niefikcjonalny - gatunek, do którego wprowadza się chwyty i techniki charakterystyczne dla gatunków znajdujących się po drugiej stronie rozróżnienia na faktualne i fikcjonalne. Jedynym, czego w ramach faction robić nie można, co narusza granice tak rozumianej strategii, jest naruszenie zasady realizmu oraz deklarowanie wbrew rzeczywistym cechom jednorodności gatunkowej, a więc - najczęściej upewnianie odbiorcy o pełnej autentyczności tekstu lub jego całkowitej przynależności do literatury faktu. 


\section{Zacieranie granic. Faction i chwyty powieściowe w biografiach}

Analizując pojęcie faction tak, jak chce rozumieć je Hartman, nietrudno dostrzec, że problem „niecelowego" mieszania gatunków jest dla rozumienia tej kategorii kluczowy. Długa dyskusja na temat granic dopuszczalnych przesunięć w obrębie literatury faktu zaowocowała odmiennymi podejściami m.in. reporterów do tego, co w reportażu jest jeszcze dopuszczalne, a co zmienia reportaż w tekst fikcjonalny. Nie jest przecież tajemnica, że rozwiązania znane z powieści niefikcjonalnej - a więc m.in. uzupełnianie opartej na faktach relacji fikcjonalnymi elementami, które mają za zadanie uczynić prowadzoną narrację pełniejszą, łatwiejszą w odbiorze czy bardziej przekonującą, przewędrowały z powieści do tradycyjnie rozumianej literatury faktu. Dobrym przykładem takiego zjawiska może być - odwołując się już do polskiego kontekstu - technika reportażowa Ryszarda Kapuścińskiego. Reporterowi zarzucano - m.in. w biografii, która wywołała skandal środowiskowy i której podtytuł brzmi właśnie „non-fiction” - „dopisywanie” do przedstawianych zdarzeń elementów fikcjonalnych (od wyolbrzymiania pewnych zjawisk czy doświadczeń, przez kreowanie nieistniejących postaci, kompilowanie relacji różnych świadków w jedną, do wymyślania sytuacji, które nie mogły w opisanym kształcie zaistnieć).

Technika ta oddaje w zupełności sposób funkcjonowania faction, lecz w przypadku reportażu, nawet literackiego, sytuuje się na granicy tego, co jeszcze dopuszczalne. Ściśle rzecz biorąc, wśród części reporterów uznaje się za dopuszczalne np. kompilowanie w relacji jednego świadka informacji pozyskanych od ich większej liczby, zwłaszcza jeśli celem takiego zabiegu jest utrzymanie ciągłości relacji i klarowności wywodu, ale już tworzenie fikcjonalnej tożsamości tegoż świadka uznaje się najczęściej za przekroczenie granicy dozwolonej interwencji w materiał faktograficzny. Podobnie jest w przypadku zastosowania podobnych zabiegów w przypadku biografii: zazwyczaj są one uznawane za już niedopuszczalne przekroczenie granicy wierności faktom.

Granica oddzielająca gatunki fikcjonalne od gatunków faktualnych jest zatem płynna: choć da się wskazać, co na pewno ją przekracza, istnieje spora klasa tekstów, które sytuują się na pograniczu gatunku. Czasem jest to efekt świadomej strategii twórcy, projektującego tekst gatunkowo niejednoznaczny, czasem zaś skutek umyślnego lub nieświadomego naginania wciąż wyczuwalnej granicy. Obie strategie prowadzą jednak do tego samego, do powolnego zacierania i tak już trudnej do dokładnego opisania granicy między wspominanymi typami literatury. By pokazać, jak ten proces przebiega 
- nawet w obrębie biografii, a więc gatunku o długiej i bardzo dookreślonej tradycji - warto odwołać się ponownie do biografii Ryszarda Kapuścińskiego, napisanej przez Artura Domosławskiego. Autor biografii bywał krytykowany - czasem nawet w dość niewybredny sposób ${ }^{21}$ - za naruszenie dobrego imienia reportera, naruszenie tym większe, że sam Domosławski był i reporterem, i przyjacielem twórcy Hebanu. Największe zarzuty dotyczyły ujawnienia lub podkreślenia we wspomnianej biografii w zasadzie trzech kwestii: wskazywania, że Kapuściński, zarówno w życiu prywatnym, jak i w ramach pracy reportera przywiązywał sporą wagę do autokreacji i był gotów naginać fakty oraz manipulować nimi dla osiągnięcia określonego efektu, relacji osobistych Kapuścińskiego, zwłaszcza - relacji z kobietami, a także skomplikowanych zależności między Kapuścińskim a władzą komunistyczną.

Oczywiście, to, co spowodowało nasiloną dyskusję wokół książki Domosławskiego, nie było tylko i wyłącznie przedmiotem krytyki. Przeciwnie, spora część pisarzy i reporterów uznała, że umiejętność napisania uczciwej i nie hagiograficznej biografii stanowi wielką zaletę autora. Warto pod tym względem zacytować fragment zamieszczonej w książce opinii Zygmunta Baumana:

Mrowi się w księgarniach od małych książek o wielkich ludziach. Jest też sporo, choć mniej, wielkich książek o ludziach małych. Tych małych książek o małych ludziach jest chyba najwięcej - ale liczyć nie warto. $\mathrm{Na}$ palcach jednej ręki zliczysz wielkie książki o ludziach wielkich. Ta książka jest jedną z nich.

Autor umie słuchać. Fotografii. Notatek w brulionie. Słów spisanych i tych, jakich Ryszard spisać nie chciał, nie zdążył lub nie uznał za warte spisywania, choć warte były (i największym przeoczenia się trafiają, choć na Ryszarda szczęście trafił mu się biograf, który na milczenie, jak i na mowę, na wiersze, jak i puste między nimi przestrzenie, ma wzrok i słuch jak mało kto wyostrzone). ${ }^{22}$

Bauman uznaje umiejętność czytania między wierszami za wielką zasługę Domosławskiego. Oczywiście, w wielu przypadkach tak właśnie jest, ale nie

21 Spór wokół książki Domosławskiego doskonale opisuje PawełZajas, wskazując na dominujące wśród polskich badaczy i reporterów stanowiska dotyczące rozpatrywania kwestii gatunkowej jednorodności reportażu, problemów fikcjonalizacji etc. Por. P. Zajas Wokół "Kapuściński non-fiction": próba podsumowania i ewaluacji dyskusji, „Teksty Drugie 2007 nr 1/2.

A. Domosławski Kapuściński non-fiction, Świat Książki, Warszawa 2010. 
sposób oprzeć się wrażeniu, że biograf niekiedy nie tyle interpretuje to, co między wierszami, lecz raczej sugeruje, że w i e, co tam jest i w i e, co oznacza to, c zego ni e ma.Wrażenie to potęguje specyficzna technika przedstawienia biografii reportera. Spójrzmy na poniższy, jeden z wielu bardzo podobnych narracyjnie fragmentów:

Kapuściński wynosi z tej historii trzy nauki. Dowiaduje się, że pisanie to ryzyko i że za napisane słowa ponosi się konsekwencje. Przekonuje się również, że słowo napisane może zmieniać rzeczywistość. Wreszcie - i tego uczy go historia z cenzorem - że powodzenie w sferze publicznej polega również na „załatwianiu” spraw nieformalnymi kanałami, na budowaniu sieci osobistych kontaktów z ludźmi władzy. Jeśli ma się kolegów tu i tam, to w razie czego pomogą. ${ }^{23}$

Domosławski podsumowuje niewiele znaczące, choć dobrze udokumentowane wydarzenie daleko idącymi wnioskami dotyczącymi życia wewnętrznego bohatera biografii. Powyższe zdania nie sugerują, lecz po prostu stwierdzają, jakie zmiany w charakterze reportera nastąpiły po określonym zdarzeniu. Biograf zachowuje się nagle tak, jakby nie tylko miał dostęp do myśli dziennikarza, lecz jakby również był w stanie wytropić daleko idące ciągi przyczynowo-skutkowe między pewnymi wydarzeniami a kluczowymi z punktu widzenia tak pisanej, odbrązawiającej biografii, postawami reportera. Bardzo możliwe, że Domosławski ma rację, ale pewne jest, że wiedzieć tego, co nauczyła Kapuścińskiego pewna historia po prostu nie może. Zmiana przypuszczenia na pewność oraz wcześniejszej strategii obserwatora na strategię narratora wszechwiedzącego (powszechna w całej biografii) jest konkretnym chwytem narracyjnym. Chwytem, który wywodzi się właśnie z powieści niefikcjonalnej, a więc opartej na faktach, lecz opisującej w i ę c e j, niż na to fakty pozwalają.

Biografia Domosławskiego nie jest oczywiście czystym gatunkowo przykładem faction. Pokazuje jednak, że techniki i chwyty zapożyczone z literatury fikcjonalnej przenikają do gatunków tradycyjnie utożsamianych z faktami. Można nawet zaryzykować twierdzenie, że to, co Domosławski zarzuca Kapuścińskiemu, a więc pewne przekroczenie granicy między reportażem a literaturą, staje się również losem wzmiankowanej biografii, która nie chce

Tamże, s. 120. 
zatrzymać się na granicy faktu i woli pracować z domysłem, nie wskazując dość jasno, co jest relacją, a co spekulacją.

Płynność granicy między relacjonowaniem lub interpretowaniem faktów a spekulowaniem na ich podstawie stanowi o podatności zarówno biografii, jak i reportażu na osuwanie się w kierunku faction. Faction dopuszcza bowiem nie tylko naruszenie granicy między relacją a spekulacją, ale nawet do niej prowokuje, sytuując w innym punkcie niż biografia czy reportaż ciężar gatunkowej jednorodności. Tym punktem nie jest $\mathrm{nakaz}$ pisania zgo d n i e z faktami i tylko z faktami, lecz zakaz pisania wbrew nim. Faction zakreśla więc o wiele szersze pole autonomii twórczej, wskazując tylko jasno, czego w obrębie pisanego w ten sposób tekstu kultury być nie może. Wszystko, co jest z faktami niesprzeczne, co jest poparte choćby częściowo materiałem faktograficznym, jest dopuszczalne. Ale - istnieje oczywiście pewne bardzo konkretne "ale" - faction w tym rozumieniu nie jest równoznaczna z literaturą faktu, a więc, ujmując sprawę nieco inaczej, faction nie może udawać tego, czym nie jest. A nie jest ani biografią, ani reportażem, ani dokumentem - choć z tych, i nie tylko tych, form może korzystać.

\section{Faction jako świadoma strategia literacka}

Opisana wcześniej biografia Ryszarda Kapuścińskiego, choć nagina część obowiązujących w ramach tego gatunku zasad, nie jest - a przynajmniej w zamyśle autora nie miała być - przykładem faction. Stanowi raczej przykład naginania zasad funkcjonowania biografii niź świadomego tworzenia tekstu, który sytuuje się na granicy faktu i fikcji. Z tej drugiej strategii korzysta jednak inna znana w Polsce biografistka, Agata Tuszyńska. Jej książka poświęcona Józefinie Szelińskiej, narzeczonej Brunona Schulza,jest jednym z ciekawszych przykładów użycia faction w przypadku biografii.

Autorka, znana z pisania wciągających i - co moim zdaniem znaczące - respektujących zasady gatunku - biografii, w tym akurat przypadku zdecydowała się sięgnąc po formę od klasycznej biografii zdecydowanie odmienną. O tej odmienności gatunkowej jesteśmy zresztą informowani już w tytule książki (Narzeczona Schulza. Apokryf), w którym, oprócz wskazania osoby, o której jest tekst, napotykamy od razu na słowo wskazujące na fikcjonalizację - apokryf.

Zanim spróbuję bliżej scharakteryzować poświęconą narzeczonej Schulza książkę, warto poświęcić nieco uwagi konstrukcji innych książek Tuszyńskiej. Były one - ze znaczącym wyjątkiem, jakim są głęboko intymne 
i autobiograficzne Ćwiczenia z utraty - poświęcone zazwyczaj osobom związanym z literaturą i sztuką. Biografie te powstawały na podstawie bogatych źródeł, a jeśli tylko istniała taka możliwość - także rozmów z osobami, których wzmiankowany tekst dotyczył. Było tak nawet w przypadkach, w których ze strony opisywanej osoby autorka początkowo napotykała na zdecydowany opór, jak chociażby podczas pisania skomplikowanej biografii Wiery Gran. Oskarżona Wiera Gran jest zresztą doskonałym przykładem techniki pisarstwa Tuszyńskiej: autorka nigdy nie przekracza granicy między rekonstrukcją faktów lub przywołaniem informacji otrzymanych od osób, z którymi rozmawiała, a przypuszczeniami, np. na temat tego, jak w określonych sytuacjach mogła się czuć Wiera Gran. Spójrzmy na poniższe przykłady:

Była ładna, nieduża, fertyczna, o kocim wdzięku, ale nie lubiła swojego ciała. Uwodziła, kokietowała, znajdowała przyjemność w zdobywaniu. Zarzucała się, wciaggała w nią, ale nie interesował jej seks. O ciele i cielesności mówiła z obrzydzeniem, o męskim pożądaniu z pogardą. Czy i to miało źródło w przeżyciach z wojny? Co tak naprawdę było jej największą tragedią? Co się zdarzyło poza występami w mieszkaniach niemieckich oficerów czy ich współpracowników? W tysiącach relacji w Yad Vashem, nawet najbardziej drastycznych, rzadko pojawiają się opisy wykorzystania seksualnego, świadectwa konieczności poddania się męskiej przemocy. ${ }^{24}$

Na rachunku brakownym z dnia 21 września 1999 roku zapisała Nigdy nie mówiłam z nikim o moim życiu seksualnym. Nigdy nie mówiłam o Bogu - oba uczucia, oba akty "robienie miłości” są zbyt intymne, zbyt silne, bym potrafita znaleźć odpowiednie stowa. ${ }^{25}$

Pierwszy fragment opisuje najpierw - dobrze udokumentowane w książce - podejście Wiery Gran do relacji erotycznych i seksualnych, później zaś ciąg pytań sugeruje, ale jedynie sugeruje, co mogło być przyczyną takiego podejścia. Drugi stanowi oszczędny cytat z notatek Gran, nieopatrzony komentarzem. W obu przypadkach granica między faktem a przypuszczeniem jest jasno zakreślona. Utrzymanie czystości gatunkowej, m.in. przez respektowanie granicy między rekonstrukcją a podaniem informacji, jest znakiem

24 A. Tuszyńska Oskarżona: Wiera Gran, Wydawnictwo Literackie, Kraków 2010, s. 280.

25 Tamże, s. 282. 
rozpoznawczym Tuszyńskiej w tekstach, które jednoznacznie można zakwalifikować jako biografie. Jednak w przypadku Narzeczonej Schulza granica ta jest nie tyle rozmyta, co - od pierwszych zdań książki - zupełnie nie istnieje. Tekst rozpoczyna się od fragmentu pisanego w pierwszej osobie i dotyczącego wspomnień oraz związanych z nimi uczuć Józefiny Szelińskiej, a więc - odwołując się do tytułu książki - otwarcie apokryficznego:

Ta fotografia jest jego dziełem. To ja. „Juna”. Długie smoliste włosy gładko zebrane do tyłu. Czarna jedwabna suknia na ramiączkach. Niewielki naszyjnik z pereł. I zmysłowa, rozchylona róża z prawej strony. Ale przede wszystkim duży dekolt i nagie ramiona. Sam mnie tak usadził, upozował [...]. Nie wiem, czy to on sprawił, że tak wyglądam. Ale na pewno on wyreżyserował takie ujęcie. Taką mnie stworzył. Czy to więc jemu chciałam się podobać? Oczy spod przymkniętych lekko powiek wydają się pewne odpowiedzi. ${ }^{26}$

Strategia Tuszyńskiej, polegająca na oddaniu głosu samej Józefinie, sprawia, że tekstu nie można czytać jako klasycznej biografii, ani - tym bardziej autobiografii. Symulowana przez drugie zdanie książki tożsamość, owo „to ja”, łączące zdjęcie Szelińskiej z osobą mówiącą w tekście, jest strategią tekstową, wykorzystującą możliwości, jakie daje właśnie faction. Książka, choć opatrzona podtytułem ,apokryf”, apokryfem w gruncie rzeczy nie jest: konwencję autobiografii rozbija nieukrywająca własnej tożsamości autorka książki, podpisana z imienia i nazwiska: Agata Tuszyńska. Jasne jest więc, że tożsamość „ja” jest wyłącznie wewnątrztekstowa, nie sięga do realnego autora książki. „Ja" tekstowe konstruuje się w narracji i poprzez nią, korzystając zarówno z rozwiązań charakterystycznych dla biografii, autobiografii, pamiętnika,jak i powieści, ale wykraczając poza ramy tych gatunków. Zamiast apokryficznej autobiografii mamy tu raczej do czynienia z gatunkiem zmąconym, z posługującą się strategią faction biografią, w której choć korzysta się z pozorowanego autobiograficznego utożsamienia między tekstowym „ja” a Józefą, to realny autor pozostaje poza owym utożsamieniem, pojawiając się zresztą w toku narracji niejednokrotnie, jako komentator dokumentów czy listów.

Książka Tuszyńskiej, choć gra z konwencją, czyni zadość głównej zasadzie faction, a więc zasadzie realizmu i niesprzeczności z faktami. Pojawiające się

26 A. Tuszyńska Narzeczona Schulza, Apokryf, Wydawnictwo Literackie, Kraków 2015, s. 7. 
w książce spekulacje nie muszą być prawdziwe, lecz nie są - a przynajmniej w świetle obecnej wiedzy na temat życia Szelińskiej i Schulza - nieprawdziwe. Zachowany więc zostaje - choć w nieco zmienionej formie - pakt referencjalny, pozwalający czytelnikowi przypuszczać, że czyta o wydarzeniach z życia konkretnej osoby, a owe wydarzenia są albo prawdziwe, albo prawdopodobne. Co ciekawe, łatwo odróżnić, które części Narzeczonej Schulza są przypuszczalnie prawdziwe, a które jedynie możliwe lub prawdopodobne. Dzieje się tak z powodu specyficznej konstrukcji książki, opierającej się na kontrastowaniu ze sobą zasadniczo odmiennych narracyjnie i strukturalnie fragmentów: niektóre mogłyby z powodzeniem znaleźć się w klasycznej biografii (to rekonstrukcje wydarzeń z życia bohaterki oraz Brunona Schulza, oparte na ocalałych listach lub relacjach - często pamiętnikarskich - świadków), inne stanowią dalsze części fingowanej autobiografii tytułowej narzeczonej, a jeszcze inne - jasno wyodrębnione - można uznać za spekulacje na temat stanów psychicznych Juny ${ }^{27}$.

Konstruowana przez Tuszyńską historia życia Józefiny Szelińskiej jest więc udanym przykładem fikcjonalizowanej biografii. Tekst, sytuujący się na przecięciu literatury faktu i fikcji literackiej, pozwala na opowiedzenie historii, która - gdyby nie użycie wspomnianych wcześniej chwytów - nie byłaby możliwa do opowiedzenia. Faction sprawdza się zatem jako strategia umożliwiająca ominięcie problemów, jakich nastręcza albo próba zbyt kurczowego trzymania się konwencji biografii, gdy nie jest możliwe pełne odtworzenie życia danej osoby, albo w sytuacji, gdy dokładne odtworzenie czyichś losów jest mniej istotne niż próba opowiedzenia - także za pomocą chwytów fikcjonalizujących - o pewnej mniej lub bardziej uniwersalnej historii, która stała się czyimś udziałem.

Faction, rozumiane nie tyle jako konkretny - choć zmącony - gatunek literacki, lecz jako praktyka lub strategia twórcza,jest moim zdaniem z jednej strony przejawem zmian, jakim ulega literatura współcześnie, z drugiej zaś

27 Niekiedy pojawiają się one jako element narracji pierwszoosobowej, czasem jednak - jako część narracji trzecioosobowej, przypominając wtedy praktykę spotykaną w tych biografiach, które spekulują na temat wewnętrznego życia bohatera. Warto pod tym względem spojrzeć na poniższy fragment: „Ale prawdziwie dotknąć musiało ją też coś innego. Autor, jej znajomy przecież, jej powiernik, którego, no może zaniedbywała trochę, lecz bardzo ceniła i obdarowywała czasem nawet czymś w rodzaju przyjaźni, Muzą Bruna nazwał - nie JĄ, JUNĘ, lecz Deborę Vogel, tę Deborę, którą przecież... Która przecież naprawdę mogła być jego muzą w czasie pisania Sklepów, ale później... Później była tylko ona, Juna!" (Por. A. Tuszyńska Narzeczona Schulza, s. 263). Spekulacja prowadzona jest tu - mimo licznych fragmentów pierwszoosobowych z zewnątrz, z perspektywy biografisty właśnie. 
- odpowiedzią na wciąż rosnącą potrzebę autentyczności oraz równoczesny brak zaufania wobec opowieści, które mają być „prawdziwe”. Grające z konwencjami, lecz nieprzekraczające konkretnej granicy - granicy utożsamienia z literaturą faktu oraz zakazu pisania o rzeczach, które nie są możliwe ani prawdopodobne - faction stanowi znak nowych czasów, w których biografie i autobiografie są jednymi z najbardziej poczytnych książek, a zarazem powszechne jest przekonanie, że coraz trudniej znaleźć wśród nich teksty, które w pełni czyniłyby zadość kryterium autentyczności i prawdziwości. Fikcjonalizowane biografie, nie dając czytelnikowi ani pewności prawdy, ani obietnicy autentyczności, oferują coś innego: realistyczną, wciągającą opowieść o czyimś życiu, która domaga się od odbiorcy krytycznego odczytania i podjęcia decyzji czy - i na ile - można ją uznać za autentyczną, choć bez wątpienia nie można uznać jej za w pełni prawdziwą.

\section{Abstract}

\section{Justyna Tabaszewska}

THE INSTITUTE OF LITERARY RESEARCH OF THE POLISH ACADEMY OF SCIENCES (WARSAW)

At the Limit of Fact: Faction in Studies on Contemporary Biographies

Tabaszewska examines the ways in which life writing can be classified into biography, autobiography and non-fiction. One example of how the borders between these genres are blurred is the category of faction (a portmanteau word of "fact" and "fiction"). this type of writing indicates the possibility of a "murky genre" that purposefully oversteps the previously unassailable borders between fiction and non-fiction. Tabaszewska explores several instances where this strategy was applied, which allows her to formulate questions about the changes that are currently taking place in literary and cultural practices in the construction of non-fictional texts.

\section{Keywords}

biography, fact, fiction, faction 